\title{
CHORDOID MENINGIOMA
}

\section{Report of two cases}

\author{
Oswaldo Ignácio de Tella Jr1, Marco Antonio Herculano², Mirto Nelso Prandini , \\ João Norberto Stavile ${ }^{4}$, Antonio de Pádua Furquim Bonatelli ${ }^{3}$
}

\begin{abstract}
We present CT scan, MRI and histopathologic findings of two patients harboring a rare type of meningioma. In the first case, a 52 year-old male patient, a large parasellar mass invading the cavernous sinus, infiltrating the infratemporal fossa and extending as low as C2 was founded. The tumor was isointense on T1, enhanced strongly with gadolinium injection, and was hyperintense on T2. In the second case, a 19year-old male patient, a large high density temporal right mass was disclosed by $\mathrm{CT}$ scan. Both patients were taken to surgery. In the first case, only a partial removal was possible to be accomplished due to a severe intra operative bleeding. In the second case, the tumor was totally removed. Both showed characteristic pathologic findings of a meningioma resembling a chordoma. Meningioma is a relatively common intracranial tumor, occurring most frequently in adults, showing a wide variety of growth patterns. We described a pattern that had a peculiar chordoma-like appearance. The pathological findings and the differential diagnosis from chordoma are discussed.
\end{abstract}

KEY WORDS: chordoid meningioma.

\begin{abstract}
Meningioma cordóideo: relato de dois casos
RESUMO - Relatamos os achados tomográficos, de ressonância magnética e histopatológicos de dois pacientes com um tipo raro de meningioma. O primeiro era um paciente de 52 anos, do sexo masculino, portador de massa para selar volumosa, invadindo o seio cavernoso, infiltrando a fossa infratemporal e se estendendo ao nível de C2. O processo expansivo era isodenso em T1, contrastando-se intensamente com a injeção de gadolíneo e espontaneamente hiperintenso em T2. O segundo era um paciente de 19 anos, do sexo masculino, com grande massa, espontaneamente hiperdensa, em região temporal esquerda, na tomografia computadorizada de cranio. Ambos foram tratados cirurgicamente. No primeiro, somente a ressecção parcial foi possível devido a presença de intenso sangramento intra-operatório. No segundo o tumor foi totalmente removido. Ambos apresentavam características patológicas sugestivas de meningioma cordóideo. 0 meningioma intracraniano é relativamente comum, ocorre em adultos, apresentando diversos tipos histológicos. O meningioma cordóideo representa forma rara deste tipo de tumor, devendo ser diferenciado dos cordomas.
\end{abstract}

PALAVRAS-CHAVE: meningiomas, cordóideo.

Meningiomas range from 13 to 19 per cent of all primary brain tumors ${ }^{1}$. The microscopic appearance of meningiomas is highly variable and has led to several rather complex and confusing classifications. The classic monograph on meningiomas by Cushing and Eisenhardt presents nine major types and twenty subtypes. Meningiomas may undergo a variety of metaplastic and degenerative changes, which are not important if differences in biologic behavior are taken into account. However, this wide variety of forms gave rise to a bewildering array of histologic patterns.
The last classification of the World Health Organization listed 11 types of meningiomas. One of these variants is the chordoid meningioma, a very rare type, that resembles a chordoma with its large areas of lymphocytic and plasma cell infiltration ${ }^{1,2}$.

This special group presents a remarkable myxoid and chordoid pattern, described in children and adolescents by Kepes et al. ${ }^{3}$. The resemblance of the tumor cells to those of a chordoma can be striking ${ }^{1,4}$. We report on two cases.

Department of Neurosurgery (OITJ, MAH, MNP, APFB), Department of Pathology (JNS), Federal University of São Paulo, São Paulo SP Brazil: ${ }^{1}$ Adjunct Professor of Neurosurgical Department; ${ }^{2}$ Associated Professor of Neurosurgical Department; ${ }^{3}$ Associated Professor of Neurosurgical Department; ${ }^{4}$ Adjunct Professor of Department of Pathology.

Received 9 January 2002, received in final form 1 August 2002. Accepted 22 August 2002.

Dr. Oswaldo Ignácio de Tella Jr - Rua São Paulo Antiga 145 Bloco F Apto 11 - 05864-010 São Paulo SP - Brasil - Fax: $5511573-6920$

E-mail: detella.ncir@epm.br 


\section{CASES}

Case 1 - This 52 year- old male patient was referred to us complaining of severe pain on the right side of the face for the last two weeks, involving mainly the frontal and maxillary region. The patient underwent an operation six years ago for a right cerebellopontine angle tumor. Histological examination revealed it to be a neurinoma. On neurological examination he had right hypoesthesia on the first and second division of the trigeminal nerve and no hearing on that side. There was also some impairment of the lower cranial nerve function, with some dysphagia and nasal speech. MRI revealed a large parasellar mass invading the cavernous sinus, infiltrating the infratemporal fossa, extending as low as C2. The tumor was isointense on $\mathrm{T} 1$, enhanced strongly with gadolinium injection and was hyperintense on T2 (Fig 1). The patient was submitted to a cranio orbito zygomatic approach, with exposition of the superior orbital fissure and foramen rotundum. The middle menigeal artery was ligated, permitting the visualization of the third division of the trigeminal nerve. Extensive drilling between V2 and V3 was done, but we decided to proceed the approach intradurally. The tumor was rather soft, very well vascularized and was removed piecemeal. Since there was a lot of bleeding, homeostasis was greatly required so we decide to perform a partial removal. Most of the tumor was extradurally removed. Fat and surgicel were left in the supratentorial part of the tumor. The tumor located in the infratemporal fossa was debulked without extirpation of the capsule. MRI was performed after the operation and showed a mass in the paraselar region around the fat tissue (Fig 2 ). The patient is doing well 3 years after the operation.

Case 2 . This 19 year-old male patient was referred to us complaining of severe right temporal headache from the last two months. Neurological examination was nor-

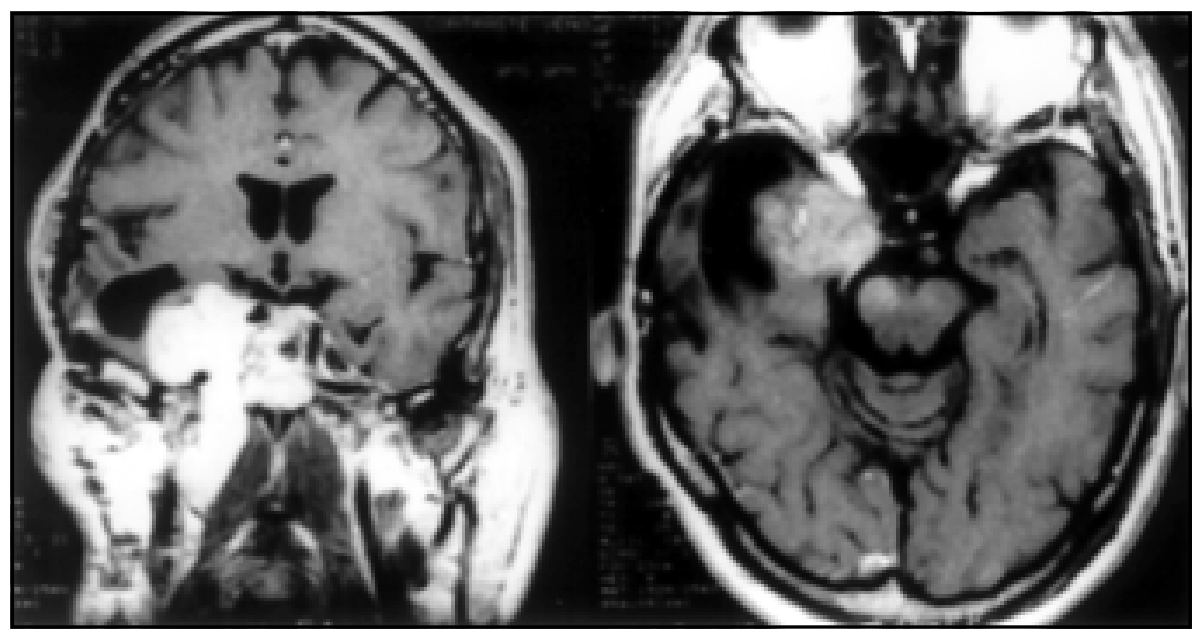

Fig 1. Case 1. MRI coronal and axial views showing a large paraselar mass distorting the temporal horn and extending to the infratemporal fossa probably through the forame ovale. Note intense enhancement after gadolinium injection.

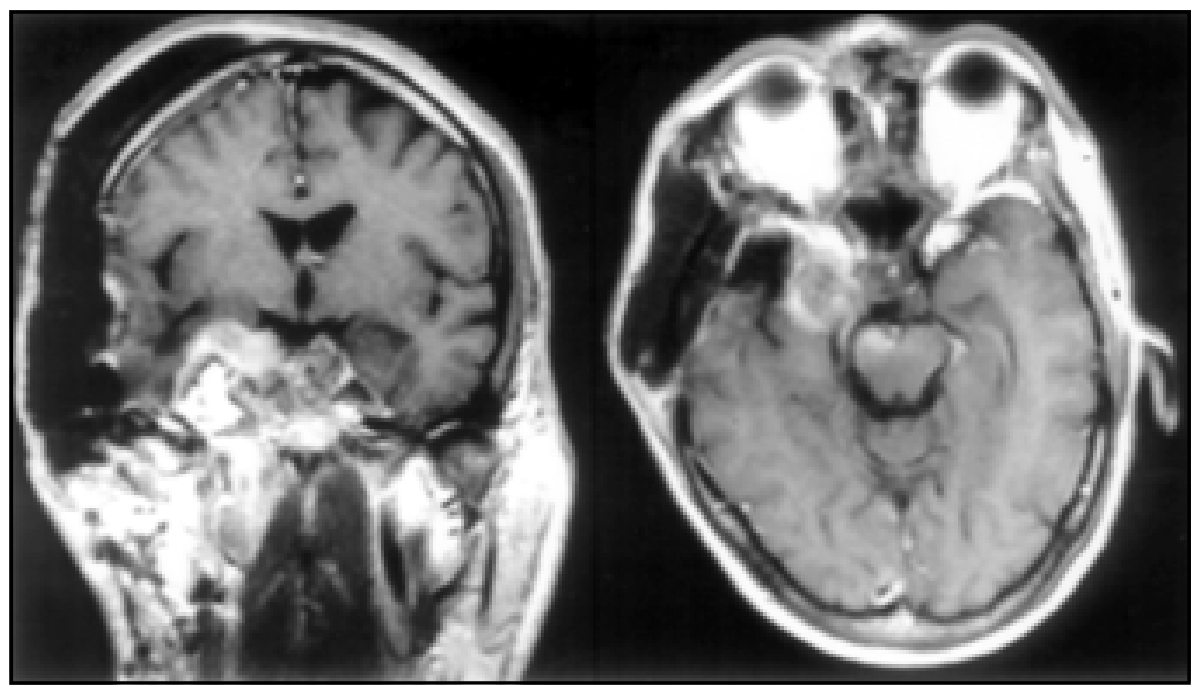

Fig 2. Case 1. MRI coronal and axial views done after the operation showing partial removal of the tumor. The hyperintense tissue inside the supratentorial compartment of the tumor is fat. 
mal. The CT scan showed a large high density right temporal mass, enhanced by contrast administration (Fig 3). A fronto-pterional craniotomy was performed and the tumor totally removed. The microscopic appearance was described as secretory meningioma. The patient was discharged home free of symptoms one week later. On his follow-up two month later a CT scan was performed, showing no abnormalities (Fig 3). The patient was assymptomatic. Five months later he returned complaining of severe headache from the last five days. The patient presented inflammatory and febrile syndromes but the neurological examination was still preserved. At that time a CT scan demonstrated a huge renewed tumor. The patient died a few hours later before surgery.

A microscopic appearance slide review showed a mixoid matrix surrounded by a small strand of meningotelial cells areas, resembling chordoma histology. This was diagnosed as a chordoid meningioma.
Histopathological findings - Multiple fragments of tumor were fixed for classical histological study in 10\% formalin; the sections were included in paraffin block, and stained with hematoxylin-eosin (HE). Immunohistochemistry was performed on paraffin sections using monoclonal antibodies to epithelial membrane antigen (EMA) and vimentin. All antisera were used with the avidin biotin complex technique and were visualized using 3,3 diaminobenzidine tetrahydrochloride substrate. Appropriate positive and negative controls were also used. Light microscopy examination revealed tumor characterized by cohesive strands of epithelial cells in a myxoid Alcian-blue positive matrix and a chronic inflammatory response consisting of lymphocytes and plasma cells but without the formation of follicles or germinal centers (Fig 4). Immunohistochemical stains showed a membranous pattern of immunoreactivity for epithelial membrane antigen and diffuse immunoreactivity for vimentin.

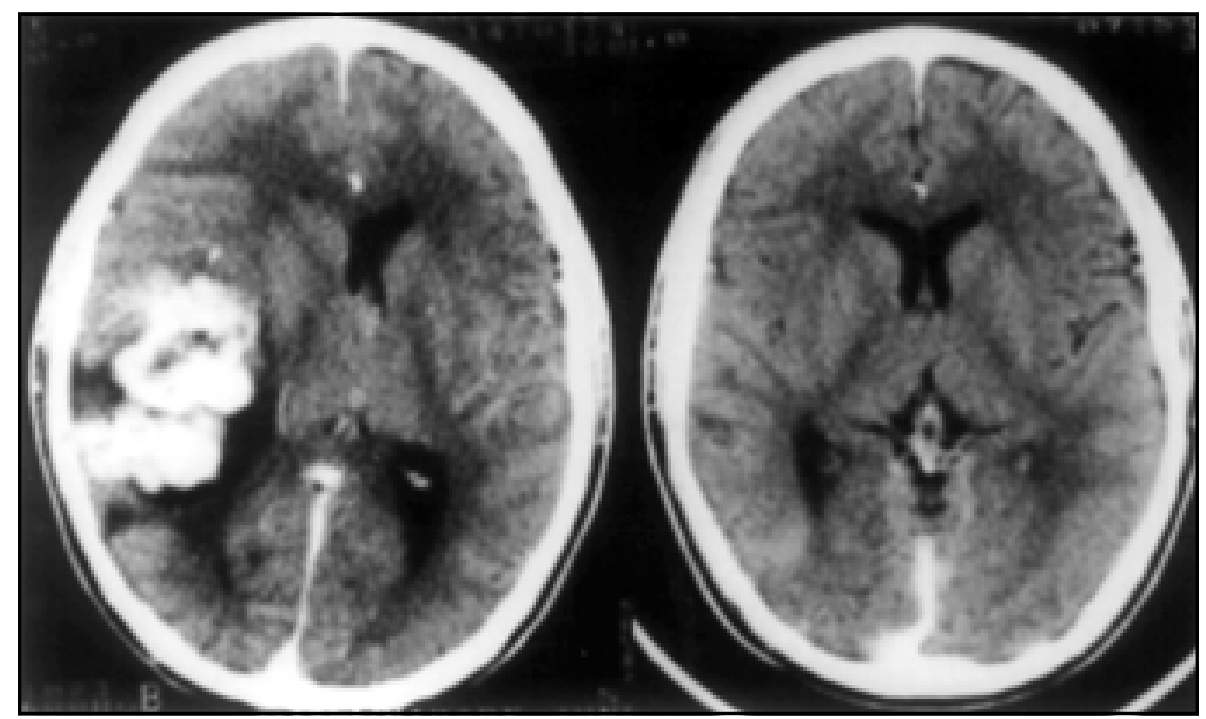

Fig 3. Case 2. CT Scan showing a large high hyperdense temporal mass after constrast injection. Normal CT Scan after two months.

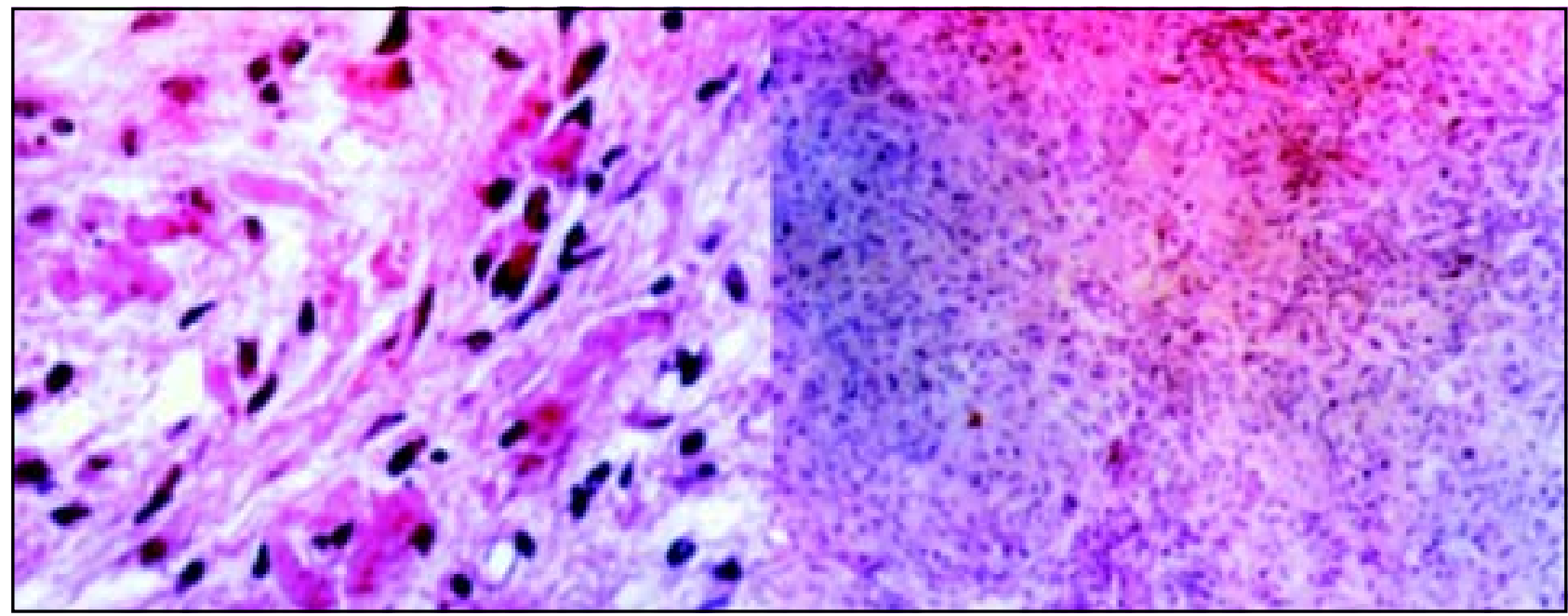

Fig 4. Light microscopy examination revealed tumor characterized by cohesive strands of epithelial cells in a myxoid Alcian-blue positive matrix and a chronic inflammatory response consisting of lymphocytes and plasma cells but without form follicles or germinal centers. $H \& E 100 x, 400 x$. 


\section{DISCUSSION}

Burger, Scheithauer and Vogel ${ }^{5-7}$ called attention to this atypical form of meningioma in their Surgical Pathology of the Nervous System and its Coverings. Meningiomas are most common in the middle decades of life, usually after the third decade, and show a marked preference for women with an overall male: female of 1:2 (intracranial meningioma, 3:2; intraspinal meningiomas, 1:10). In order of incidence, intracranial meningiomas occur in the following locations: parasagittal and free convexity accounting for almost $50 \%$ of the cases, followed by sphenoid ridge, tuberculum sellae, olfactory groove, foramen magnum, optic nerve, tentorium cerebelli, and choroid plexus ${ }^{1}$. The commonly recognized histological subtypes display both mesenchymal and epithelial features. Mesenchymal metaplastic changes include xanthomatous, lipoblastic, myxoid, chondroid and osteoblastic differentiation, while evidence of epithelial differentiation includes the presence of papillary structures, "epithelial" markers (EMA, EGF), and desmossomal attachments".

The chordoid meningioma is a rare variant with a myxoid pattern and cords of epithelioid cells similar to that a chordoma ${ }^{8}$. A prominent lymphoplasmocytic infiltrate may be seen in some. Patients can present with iron-refractory anemia and polyclonal gammopathy (Castleman's syndrome), both of which remit with ressection but reappear upon recurrence ${ }^{9,10}$. This variant may have prognostic significance since a number have behaved in an aggressive manner ${ }^{11}$.

Vagner-Capodano et al. published the correlation between cytogenetic and histopathological findings in 75 meningiomas and observed complex chromosomes abnormalities and telomeric associations in tumors that histologically display certain degree of anaplasia ${ }^{12}$. From the histological point of view, they found transitional type in 33\%, meningothelial in $29 \%$, fibrobalstic in $9 \%$, psammomatous in 3\%, chordoid in $1 \%$ and mixed tumors in $24 \%$. They did not specify the location and the other features of the chordoid group. Civit et al. report a tuberculum sellae meningioma in a 21 years old woman who presented with Castelman syndrome and the final pathological result was a chordoid meningioma ${ }^{13}$. Alameda et al. report a case which tumor was located in the lumbosacral spine. They refer that the dif- ferential diagnosis with other neoplasm, particularly metastatic carcinoma, is often difficult ${ }^{14}$.

The report of this rare type of pathology hopes to call attention to this specific type of meningioma.

\section{CONCLUSION}

In conclusion, the diagnosis of malignancy in patients with meningiomas has been a controversial issue. Only a histological study can confirm this situation. The association of pathological examination and imnunohistochemical study can make a diagnosis of chordoid meningioma. Civit et al. say that the literature has shown that chordoid meningiomas display several areas of physaliferous cells, which give the tumor a chordoma-like aspect ${ }^{13}$. The patient presenting with an intracranial meningiomas usually has a indolent course of symptoms depending on its location. A critical evaluating of the two cases here presented and the recurrence after surgery call attention to a non benign form of meningioma of chordoid type.

\section{REFERENCES}

1. Russel DS, Rubinstein LJ. Pathology of tumors of the nervous system. 5.Ed. Baltimore: Williams \& Wilkins, 1988:452-505.

2. Kleihues P, Burger PC, Scheithauer BW: Histologic classification of tumors of the central nervous system. New York: Springer-Verlag, 1993.

3. Kepes JJ, Chen WY, Connors MH, Vogel FS. "Chordoid" meningeal tumors in young individuals with peritumoral lymphoplasmacellular infiltrates causing systemic manifestations of the Castleman syndrome: a report of seven cases. Cancer 1988;62:391-406.

4. Cerasoli S, Gubinelli M, Tison V, Vergoni G, Morigi F, Cenacchi G. Chordoid meningioma: case report. Brain Pathology 1994;4:439.

5. Burger PC, Scheithauer BW, Vogel FS. Surgical pathology of the nervous system and its coverings. 3.Ed. New York: Churchill Livingstone, 1991.

6. Burger PC, Scheithauer BW. Tumors of the central nervous system. Washington: Armed Forces Institute of Pathology, 1994.

7. Ellison D, Love S, Chimelli L, et al. Neuropathology. London, Mosby, 1998;43:1-14

8. Zuppan CW, Liwnicz BH, Weeks DA. Meningioma with chordoid features. Ultrastruct Pathol 1994;18:29-32.

9. Glasier CM, Husain MM, Chadduck W, Boop FA: Meningiomas in children. MR and histopathologic findings. Am J Neuroradiol 1993;14:237-241.

10. Göden M, Roth KA, Carroll SL, Wick MR, Schmidt RE. Clear cell neoplasms and pseudoneoplastic lesions of the central nervous system. Semin Diagn Pathol 1997;14:253-269.

11. Kobata H, Kondo A, Iwasaki K, Kusaka H, Ito H, Sawada S: Chordoid meningioma in a child: case report. J Neurosurg 1998;88:319-323.

12. Vagner-Capodano AM, Grisoli F, Gambarelli D, Sedan R, Pellet W, De Victor B. Correlation between cytogenetic and histopathological findings in 75 human meningiomas. Neurosurgery 1993;32:892-900.

13. Civit T, Baylac F, Taillandier L, Auque J, Hepner H. Chordoid meningiomas: clinical, neuroradiological and anatomopathological aspects. A propos of a new case and review of the literature. Neurochirurgie 1997;43:308-313.

14. Alameda F, Lloreta J, Ferrer MD, Coraminas JM, Galito E, Serrano S. Clear cell meningioma of the lumbo-sacral spine with chordoid features. Ultrastruc Pathol 1999;23:51-58. 